\title{
PROBLEMS OF CUSTOMS CONTROL IN THE CONTEXT OF EUROPEAN INTEGRATION OF UKRAINE
}

\author{
Orest Krasivskyy ${ }^{1}$, Viktoria Tovt ${ }^{2}$ \\ ${ }^{I}$ Doctor of History, Professor, Head of the Department of European Integration and Law of Lviv Regional \\ Institute for Public Administration of the National Academy for Public Administration (LRIPA NAPA), Lviv, \\ Ukraine, e-mail: krasivski@ukr.net, ORCID: https://orcid.org/0000-0002-7028-6038 \\ ${ }^{2}$ Postgraduate student of the department Euro integration, Lviv Regional Institute for Public Administration \\ of the National Academy for Public Administration under the President of Ukraine, Lviv, Ukraine, e-mail: \\ tovtviktoriya@gmail.com, ORCID: https://orcid.org/0000-0003-1046-600X
}

\begin{abstract}
In the article is considered customs control, as minimizing instrument of negative tendencies and phenomena that occur during crossing the border. That's why the relevance of the study is stressed by the important factor in ensuring the rule of law on the customs border of Ukraine with the neighbouring countries. The official beginning of cooperation between Ukraine and the European Union was international legal relations, founded in 1991 by the Minister of Foreign Affairs of the Netherlands, which officially recognized the independence of the Ukrainian State. ustoms control, in our opinion, represents set of funds, actions, events and operations of specialized power bodies which are allocated for preventing offenses in the sphere of crossing of goods and vehicles through Customs Border of the State, and to prevent emergence of undesirable consequences, caused by non-compliance with the Customs Legislation. Customs control is part of the general system of implementation of control actions, the important is understand the essence of control which is considered in article as comparison of planned indicators of functioning of object with real indicators of its activity and the acceptance on this bases relevant management decisions in order to provide realization of the purpose and tasks of control actions set in the direction of achievement of the corresponding results. In the direction of realization of European integration aspirations of Ukraine our state needs to strengthen customs control in order to ensure the protectionist policy of the Ukrainian State and the conformity of customs operations with common European values and common practice of customs legal relations in the European Union. It is necessary to ensure compliance with Legislation in all spheres of implementation of customs policy and to strengthen the responsibility of officials of customs authorities of Ukraine for noncompliance with or malicious violation of Customs Legislation.
\end{abstract}

Keywords: control, customs control, customs system, customs control bodies, control procedures.

JEL Classification: E30, F17, F18, F19, H20, K34

Formulas: 0; fig.: 0; tabl.: 0; bibl.: 21

Introduction. Historiography of the development of customs control in the context of the development of relations between Ukraine and the European Union is substantiated. It is argued that customs control occupies an important place in the system of types of control, taking into account implementation of a number of inspections related to crossing the customs border of the state by goods. The signs of customs control are defined based on international practice and modern realities of development of the Ukrainian state.

In current conditions of development of the Ukrainian society, customs is of particular importance in the context of the need to expand foreign economic relations, to align them with world standards and to realize the European integration aspirations of the Ukrainian state. Customs control plays an important role in shaping the country's customs system. System of relations in the field of customs control is 
intended to ensure and guarantee economic security and national interests of the Ukrainian state.

However, instability of socio-economic development of the state is the cause of considerable abuse in the field of crossing by goods and vehicles of the customs border of the state. This implies the need to take harsh measures to fight against abuses and offenses at the customs border. Customs control is a tool designed to minimize negative trends and phenomena, as well as their consequences in this field. Therefore, a clear understanding of essence and features of customs control is an important factor in ensuring the rule of law and order at the customs border of Ukraine.

Literature review. At present, a considerable number of scientists study the specific features of customs control, considering this multidimensional issue from different perspectives. In particular, it is worth to mention such scientists as I. Berezhnyuk, M. Bilukha, Y. Hupanova, A. Yershov, T. Kalinescu, A. Krysovatyi, V. Martyniuk, T. Mykytenko, V. Naumenko, P. Pashko and others.

Their works are dedicated to the general problems of organization of customs control, administration of customs activity in Ukraine and to the role of customs in the system of state administration bodies. However, dynamic changes in Ukrainian society determine the need for a deep and unified understanding of the essence of customs control in line with current realities, which necessitates further scientific research in this direction.

Aims. The purpose of the article is to analyze approaches to understanding of the essence of the concept of control and its important component - customs control, as well as to reveal signs and specific features of customs control in modern conditions.

Methods. The main research methods used in the article are the method of abstraction, analysis and synthesis, comparison. Based on these methods, the goal set in the article was achieved.

Results. In order to understand the essence of customs control and its specific features better and more deeply, first of all we shall consider what is control in its original sense. This concept has long-standing roots, because it was formed and developed along with development of social relations. It is based on the French word "controle", which means "juxtaposition".

In modern scientific literature, "control" is interpreted as a multifaceted concept. It is considered from the standpoint of systematic observation and verification of vital activity of particular object in order to determine its deviations from the parameters defined in advance. Specific feature of control in this case is determined by the fact that administrative bodies check the compliance of the object with the tasks and instructions set before it.

Scientists consider the concept of control in the context of comparing (juxtaposition or contraposition) several statements [1] or as a counteraction to something undesirable [2].

International legal framework for cooperation between Ukraine and the European Union dates back to 1991, when the Dutch Foreign Minister, who presided 
at the time in the European Union, formally recognized the independence of the Ukrainian state. Since then, the Ukrainian party has been able to claim objective and mutually beneficial cooperation with European Union countries, being a full member of such relations.

Strategic plans for development of customs in the European Union and aspirants for membership (in particular Ukraine) defined by the integration processes are outlined in the EU Customs Prototypes by defining certain standards. These are a comprehensive and stable system of customs legislation; a mechanism for customs cooperation with national and international law enforcement agencies; introduction of the latest information technologies at customs; simplification of customs procedures; customs risk identification mechanism; effectiveness of customs audit and post-audit as of forms of customs control.

Obviously, the common border between Ukraine and the EU mean that the parties should establish relations in the field of cross-border cooperation, settlement of border relations, development of customs policy, which would be able to ensure effective contacts between the parties. Customs policy is based on a legal framework that is aimed to resolve issues related to the imposition of duties, crossing the customs border by the goods, development of customs tariffs and cooperation in customs regulation.

Control itself, as stated in Lima Declaration on the Principles of Financial Control, "is not an end in itself, but rather an integral part of the regulatory system, which seeks to identify deviations from accepted standards and violations of the principles of legality, efficiency and economy of material resources at the most early stage in order to be able to take corrective actions and, in some cases, to prosecute, obtain compensation for damage caused to the State, or to take measures for prevention or reduction of future violations"[3].

The Customs Service of Ukraine is an important element in the system of the state administration the important element. It is designed to implement the customs policy of the State and to carry out the customs activity in the context of globalization processes. The Customs Service affects public, economic, political and other spheres of human life in the country, so its role cannot be overestimated.

Legal, economical and organizational basics of Customs activity are defined in the Constitution and laws of Ukraine, the Normative Acts of the President of Ukraine, the Cabinet of Ministers of Ukraine, the Acts of the State Customs Service and other central executive bodies. The Customs Service is primarily called upon to carry out its integrity function in the sphere of ensuring the integrity and inviolability of the borders of the Ukrainian State. This is stated in the legislation of Ukraine, in particular in the Basic Law. Thus, the Constitution of Ukraine states in the Article 2 that "the sovereignty of Ukraine extends to its entire territory, which is within the existing border, is holistic and inviolable". In the Article 17 Part 1 is said, that "protection of the sovereignty and territorial integrity of Ukraine, ensuring its economic and information security are the most important functions of the State, the entire Ukrainian people" [4]. Exactly these functions are giving to the Customs Service. 
Among the legislative acts in the field of customs activity, the special place belongs to the Customs Code of Ukraine, which is making the basic of Customs Legislation of Ukraine. According to its character it is the complex Legislation Act, which is regulating different relations, which are subject of regulating of administrative, civil, criminal and international law. The Customs Code of Ukraine defines: "Customs Policy is the system of principles and directions of activity of the State in the field of ensuring its economic interests and security through customstariff and non-tariff measures of regulation of foreign trade" [5]. Customs Policy is implemented by customs authorities and implemented in the context of realization by the Customs Service.

The important aspect of the Customs Policy implementation is regulation of foreign economic activity. Foreign economic activity is the activity of domestic and foreign economic entities based on the relations between them, which take place both on the territory of Ukraine and abroad [6]. The establishment of foreign economic activity is one of the tasks of economic policy and national security of each country.

In the current conditions of economic development of Ukraine and expansion of foreign economic relations, Customs Legislation is of particular importance. It defines the principles of organization of customs affairs in Ukraine with the view to, on the one hand, creating favorable conditions for the development of the economy and foreign economic relations, and, on the other hand, protecting and ensuring the constitutional rights and freedoms of citizens, the State, business entities of all forms of ownership and respecting the rules established in this important area of the legal regulation.

Thus, the Customs Policy is based on realization of norms of Customs Legislation, which is designed to solve the most important tasks:

- providing the organization and functioning of unified, coherent, stable Customs System, strengthening the legal mechanisms for the interaction of all its elements;

- defining of the general principles of regulating of the Customs Relations;

- protection of economic interests of Ukraine;

- providing compliance with obligations arising from international treaties of Ukraine concerning customs actions;

- establishment of legal norms ensuring protection of consumer interests and compliance of participants of foreign economic relations with state interests on the foreign market;

- creation conditions for effective fight with smuggling and violations of Customs Regulations, control of foreign exchange transactions;

- improvement of the level of organizational and legal guarantees of subjects of customs relations, improvement of the system of their responsibility.

On the basis of this enumeration and today's realities, it can be concluded that not all legislative provisions are implemented in the Ukrainian society in practice. In particular, this is related to the creation of conditions for fight with smuggling and abuse in the sphere of foreign currency exchange transactions. In order to overcome the negative phenomena that occur in the area of illegal crossing of Ukraine's borders, 
the political will of the State authorities and the enforcement of Ukrainian and international legislation are needed.

It is worth paying attention to such a moment. In the context of Ukraine 's desire to become a member of the European Union, efforts should be directed to overcome negative trends that exist in the field of Customs Policy, the functioning of customs authorities and the strengthening of customs control at the borders between Ukraine and European States. After all, the situation that currently reigns on the border with Poland, Romania, Hungary gives no reason to talk about transparency and openness of Customs Policy from the Ukrainian side of relations of subjects of European integration interaction.

In the direction of realization of European integration aspirations, our State needs to strengthen customs control in order to ensure the protectionist policy of the Ukrainian State and the conformity of customs operations with common European values and common practice of Customs Legal Relations in the European Union. It is necessary to ensure compliance with the Legislation in all spheres of implementation of Customs Policy and to strengthen the responsibility of officials of customs authorities of Ukraine for non-compliance with or malicious violation of Customs Legislation. In general, the effective implementation of Customs Policy is prerequisite for the harmonious development of Ukraine in modern society and is the basis for the sustainable political, economic and social development of the State.

Researchers I.K. Thrush and V.O. Shevchuk interpret control as a type of relations, as an entity's attitude to its own activity or to that of other entities in terms of compliance with certain norms. In their view, control as a type of activity is an action, the content of which in comparing several values that characterize the norms and the degree of their attainment. Introduction of controls is an integral part of administration of public financial resources, ensuring the responsible and accountable nature of this administration [7].

In scientific literature, the term "control" can be considered in two ways: as an element of management of economic entities and processes, which is to monitor them in order to check their compliance with the condition, envisaged by law, legal regulations and programs, plans, contracts, projects, agreements; and as control over the entity, real power, concentration of administrative rights in the single pair of hands [8].

Control is often an element of control and audit activity, according to which the researchers substantiate the concept of control, which reduces its essence to checking the compliance with legislation and detection of violations, defects [9-10].

Therefore, it we can argue, that control itself is not passive, but rather plays an active role in efficient use of resources and reduction of adverse effects from irrational actions of the entity under administration. Accordingly, E. Kocherin believes that control, being one of the main functions of administration, enables, through well-established control activities, timely implementation of the management system, adjustent of production tasks, improvement of reporting and so on. Effective management of the system requires feedback, which is implemented through control, is its core and extends to all production management processes [11]. 
Summarizing the presented approaches to understanding the essence of the concept of "control", we can conclude that it does not have an unambiguous interpretation - different researchers evaluate it from different positions, and often they have significant contradictions. This situation is largely explained by the fact that the state lacks a single regulatory interpretation of this definition, and because of this, it is not possible to represent the unambiguous definition of control.

Considering the focus of control as an audit activity, it can, in our view, be considered as a comparison of planned indicators of the entity's activity with the real ones, and taking, on this basis, appropriate administrative decisions in order to ensure the achievement of goals and objectives of the control actions, set for achieving appropriate results. On this basis, the control will allow to influence the entities under control and to detect quantitative and qualitative deviations from the standards and rules that correspond to the most optimal operation of the entity.

Customs control is an important part of the system of controls, since its implementation involves a number of verification actions related to the crossing of customs border of the state by goods. It acts as the content of customs procedures; it is carried out exclusively by the customs authorities; and, together with customs clearance, payment of customs duties and procedure for performing customs operations, constitutes the totality of components of the customs system of Ukraine.

Customs control has normative regulation: Customs Code states that it is "a set of measures taken to ensure compliance with the rules of the Customs Code of Ukraine, laws and other legal acts on matters of state customs and international treaties of Ukraine, concluded in accordance with the procedure established by law. All goods, commercial vehicles that move across the customs border of Ukraine are subject to customs control" [12].

Kyoto Convention defines the concept of customs control as "a set of measures taken by the customs service to ensure compliance with customs legislation" [13].

The modernized European Union Customs Code of 2008, under the "control of the customs authorities" understands "special actions taken to enforce customs and other rules applicable to goods, namely: inspection of goods, checking the availability and correctness of documents, checking accounts and other records, inspecting vehicles, luggage and personal belongings, filing official inquiries, etc.". The term "supervision of the customs authorities" is also used; it is defined as "the totality of actions of the customs authorities, which are carried out to ensure the implementation of customs and other rules applicable to goods" [14].

Along with the normative definition, in the scientific literature there are many approaches to understanding of this concept. Thus, V.P. Martyniuk considers customs control as a component of the customs system, which in turn is "a set of tariff and non-tariff instruments, principles, forms and methods of their establishment, change or cancellation; a mechanism that ensures timely and full payment of customs duties, liability for violation of customs legislation; as well as state bodies, which are entrusted with the responsibility to implement the policy in the field of state customs" [15]. 
Y.M. Diomin is convinced that customs control is "a system of statutory measures taken by customs authorities to ensure compliance with the requirements of customs and tax legislation, protection of state and public security, economic interests, as well as detection and prevention of unlawful actions by individuals and legal entities" [16].

It is a highly effective and comprehensive instrument for ensuring national interests of the state, which, in the opinion of the scientist, is a mean of implementation of state customs and represents a set of measures to ensure the requirements of customs legislation by all the participants of customs relations [17].

This authorial position contains an administration context, based on which it is quite fair to speak about ensuring the fulfillment by the state of its basic functions, in particular, administrative functions. In continuation of this, definition of customs control as "a function of management of customs transactions of entities engaged in foreign economic activity in order to ensure compliance with the requirements of legal acts on matters of state customs and international treaties of Ukraine" is worth mentioning [18].

Thus, customs control, in our view, is a set of means, measures, actions and operations of specialized authorities that are aimed at preventing offenses in the area of crossing the customs border of the state by goods and vehicles and preventing undesirable consequences, caused by non-compliance with customs legislation. Customs control shall be carried out in accordance with the features inherent thereto: customs authorities implement control and verification measures in the form of customs control; customs control contributes to the effective regulation of foreign economic activity by detecting and preventing offenses in the area of crossing the customs border by goods and vehicles crossing.

Based on international standards, customs control has the following features: implementation of control procedures should be limited to the minimum number of operations required to ensure compliance with customs legislation; use of an effective risk management system in the process of customs control; most appropriate use of information technologies and electronic communications.

Customs control is implemented by the customs control authorities, thus providing the function of verification of legality of movement of goods and vehicles cross the customs border. In course of the customs control procedures, not only goods involved in foreign trade transactions are checked, but also the level of customs commercial fraud aimed at smuggling is reduced.

Customs control forms a coherent system of measures, an integral part of which is the risk management system. Introduction of risk-oriented customs control into the customs practice enables formation of a control system based on the positive experience of customs administration implemented by foreign countries. In turn, the system includes the subsystem of control over the movement of goods across the customs border by citizens.

Discussion. In general, elements of customs control are the following: organization of customs control, risk management system, subsystem of control over movement of goods across the customs border by citizens; and the main components 
of customs control are the customs control process itself, its forms, customs expertise, customs control zones and special procedures [19].

In general, based on theoretical approaches to understanding the essence of customs control, we can see that the concept under study is diverse and ambiguous. Given that customs control is an integral part of the customs system, the study of the nature and features thereof is a priori an important task of modern scientific research.

Conclusions. Therefore, given that customs control is part of the overall control system, it is important to understand the nature of control. In the article, it is considered as a comparison of planned indicators of the entity's activity with the real ones, and taking, on this basis, appropriate administrative decisions in order to ensure the achievement of goals and objectives of the control actions, set for achieving appropriate results.

Customs control plays an important role in the system of controls and is a set of means, measures, actions and operations of specialized authorities that are aimed at preventing offenses in the area of crossing the customs border of the state by goods and vehicles and preventing undesirable consequences, caused by non-compliance with customs legislation. Carrying out customs operations for customs control is an important task of the state.

Perspective of further scientific research in this area is to study the features of customs control in the context of Ukraine's aspirations for European integration and to bring control procedures in line with European standards.

Author contributions. The authors contributed equally.

Disclosure statement. The authors do not have any conflict of interest.

\section{References:}

1. The Verkhovns Rada of Ukraine (1993), The Law of Ukraine "About Foreign Economic Activity”, .April 161991 №959. Ukrainian Customs. Reference Book, Moscow: Libra, 1993, 120 p.

2. Bakumenko, V. D. (2003), Philosophical and methodological basis of state and management decisions. State management: philosophical, worldview and methodological problems. Kyiv : Millennium, p. 147-169.

3. Bardash, S. V. (2013), Methods of control in the sphere of economic management: theoretical and praxeological aspects, retrieved from : soskin.info/userfiles/file/2013/9-10./Bardash-Osadcha.doc.

4. Becker, G. S. (2003), Human behavior. Economic March. Publishing House of the State University "Higher school of Economics", 174 p.

5. Berezhniuk, I. G. (2009), "Customs Regulating of Ukraine: national and international aspects", Academy of Customs Service of Ukraine, $543 \mathrm{p}$.

6. Bilukha, M. T. (2014), "Customs control: organization and methodology", Scientific Bulletin of the National University of the STS of Ukraine, p. 181-187.

7. Butynets, F. F. (2001), Audit and revision of business activity. PE "Ruta", 416 p.

8. Butynets, F. F. (2016), "Integrated accounting as way of enterprise management", Accounting, analysis and audit: problems of theory, methodology, organization, № 2, p. 12-24.

9. The Verkhovns Rada of Ukraine (2012), The Law of Ukraine "Customs Code of Ukraine”, № 44-45, Art.552.

10.The Verkhovns Rada of Ukraine (2012), The Law of Ukraine "Customs Code of Ukraine", March 2012, retrieved from : http://zakon1.rada.gov.ua/laws/show/4495-17/page18.

11.Diomin, Yu. M. (2009), Customs Law of Ukraine. Centre of Educational Literature, 232 p.

12.Drozd, I. K. (2007), State Financial Control. Imex-Ltd, 304 p.

13.Hodovanets, O. V. (2016), "Customs control : essence and economic contest", Scientific Bulletin of Kharkiv State University. Series Economic Sciences. Issue 20. Part 1. Pp. 159-163.

14.International Convention on the Simplification and Harmonization of Customs Procedures (Kyoto Convention) of 18 May 1973, retrieved from : http://zakon5.rada.gov.ua/laws/show/ en/995_643/page. 
15.Kocherin, E. A. (2017), Basics of the state and management control. Informational and Publishing House "Filin", 384 p.

16.Martyniuk, V. P. (2010), "On the expediency of using the term "Customs System of the State", Customs Security, № 2, p. 144-145.

17.Melnik, M. V. (2007), Audit and Control : Educational Manual. KnoRus, 520 p.

18.Regulation (EC) No 45012008 of the European Parliament and of the Council of 23 April 2008 laying down the Community Custom Code (Modernized Customs Code). Official Journal of European Communities, L 145, pp. 1-67.

19. Romaniv, M. V. (2000), "Formation and development of the state financial control in Ukraine", Abstract of Ph.D. dissertation, Economics, 189 p.

20.Lukyanchuk, P. (2020). Trade union control in the context of trade union relations with public administration entities in Ukraine. Public Administration and Law Review, (3), 41-48. https://doi.org/10.36690/2674-5216-2020-3-41.

21.Tešanović, B., Neševski, A., \& Krmpot, V. (2020). Certain aspects of economic relations between Serbia and Germany. Economics, Finance and Management Review, (1), 26-36. https://doi.org/10.36690/26745208-2020-1-26-36.

Received: October 27, 2020 Approved: November 20, 2020 